\title{
ANALISIS METODE KANBAN DAN METODE JUNBIKI PADA PERSEDIAAN PART MUFFLER DI PT. XYZ
}

\author{
Edi Susanto ${ }^{1}$, Afriandy Barus ${ }^{2}$ \\ Jurusan Teknik Industri - Institut Teknologi Nasional (Itenas) ${ }^{1,2)}$ Bandung, Indonesia \\ PT. HMMI - Plant ${ }^{2}$ Purwakarta, Indonesia \\ Email : edsusanto@itenas.ac.id, susanto.edi19@gmail.com
}

\begin{abstract}
PT. XYZ is a company main business automotive manufacturing. In producing the vehicle, the company uses a wide variety of parts, and which are part muffler. In the storage part mufflers require a fairly wide area, because there are 4 types of parts muffler with the same amount of container that is used pallet containing 30 pcs to be stored in accordance with the indications of the respective part. Part muffler having too much stock so that the buildup. When supply process takes a long time and area inventory requires a large area and that a lot of man power.

In a problem that occurs in PT. XYZ, the authors analyze and compare methods that have been applied, the Kanban method and Junbiki method, where the two systems will produce a comparison in terms of man power requirements (labour), work time and inventory area.

With Junbiki method which has the concept of zero inventory, then the result analysis shows that by using the Junbiki method to the needs of area per period can be reduced $91 \%$, labor requirements can be reduced by $20 \%$ and for a time requirement handling and supply can be reduced by $22 \%$, The research proves that Junbiki method better than the kanban method.
\end{abstract}

Keywords : Kanban Method, Junbiki Method, Inventory.

\section{PENDAhUluan}

Menurut Yoshiro Monden (1995) metode Kanban yaitu suatu kartu perintah produksi yang berfungsi untuk mengontrol persediaan, bentuk kanban adalah semacam "kartu vinil segi empat" yang dimasukkan ke dalam kantong plastik transparan dan ditempatkan pada palet tempat komponen suku cadang atau material. Metode kanban produksi diterapkan dengan merencanakan aliran Kanban yang efisien. Perencanaan metode Kanban perlu digunakan secara optimal untuk dapat mengendalikan persediaan. Proses produksi ini dapat dicapai apabila perusahaan akan memproduksi produk yang dibutuhkan sesuai dengan jumlah permintaan. Dalam perusahaan, metode Kanban yang dilihat masih belum sempurna untuk mencapai semua tuntutan pengurangan biaya, efisiensi persediaan, efisiensi waktu dan efisiensi area, maka dari itu lahir metode Junbiki, yang merupakan metode baru yang diterapkan pada perusahaan.
Junbiki berasal dari bahasa Jepang yang berarti persiapan, adalah urutan produksi yang berada di lini produksi sama dengan urutan yang diproduksi di pemasok. Hal ini sangat menunjang pelaksanaan sistem JIT (Just In Time) dan dapat mengurangi persediaan seminimal mungkin, dengan kata lain Junbiki adalah "suatu sistem pengiriman yang menggunakan sistem pemesanan dengan menggunakan faksimili atau email yang sesuai dengan heijunka pattern (urutan produksi) di lini produksi". Metode Junbiki baik digunakan pada tingkat produksi dan variasi yang besar, sebaliknya semakin kecil volume produksi, maka metode Junbiki semakin tidak efektif. Peningkatan performansi JIT ini akan terus menjadi baik apabila volume produksi bertambah banyak karena metode Junbiki akan semakin efektif apabila digunakan pada jumlah produksi yang bervariasi dan dalam jumlah yang banyak (Ohno, 1995). 
Salah satu penghematan pada metode Junbiki adalah efisiensi dalam sektor tenaga kerja, waktu kerja, area persediaan, dan efisiensi konsumsi energi. Terlihat bahwa kedua metode menunjukan penggunaan sumber daya yang efisien, tetapi apabila dibandingkan, maka untuk pemakaian energi, keduanya berimbang, kondisi ini disebabkan oleh faktor produksi, sedangkan pada sistem Kanban, besarnya energi yang dikeluarkan ditentukan oleh tingkat produksi. Dari kondisi dapat dinyatakan bahwa metode Junbiki lebih baik diterapkan untuk tingkat produksi yang besar. PT XYZ dalam memproduksi kendaraannya menggunakan berbagai macam barang, dan diantaranya adalah part muffler. Part muffler adalah komponen kendaraan bermotor yang berfungsi untuk mengurangi noise / kebisingan suara yang muncul dari proses pembakaran mesin. Dalam penyimpanannya part muffler membutuhkan area yang cukup luas, karena ada 4 jenis part muffler dengan jumlah kemas yang sama yaitu menggunakan pallet yang berisi 30 pcs yang harus disimpan sesuai dengan indikasi masing - masing part tersebut. Part muffler mempunyai stok yang terlalu banyak sehingga terjadinya penumpukan yang berakibat kepada proses pendistribusian membutuhkan waktu yang lama dan area penyempinan persediaan membutuhkan area yang luas serta tenaga kerja yang banyak.

Penelitian ini bertujuan untuk membandingkan antara kedua metode tersebut dengan menganalisis perbandingan keduanya untuk mendapatkan metode persediaan didalam perusahaan yang lebih efektif.

\section{METODOLOGI PENELITIAN}

Metode penelitian yang digunakan oleh penulis adalah serangkaian langkah - langkah yang sistematis dan logis untuk memberikan pedoman dan kemudahan dalam melakukan analisis perbandingan terhadap metode Kanban dan metode Junbiki seperti gambar 1 berikut :

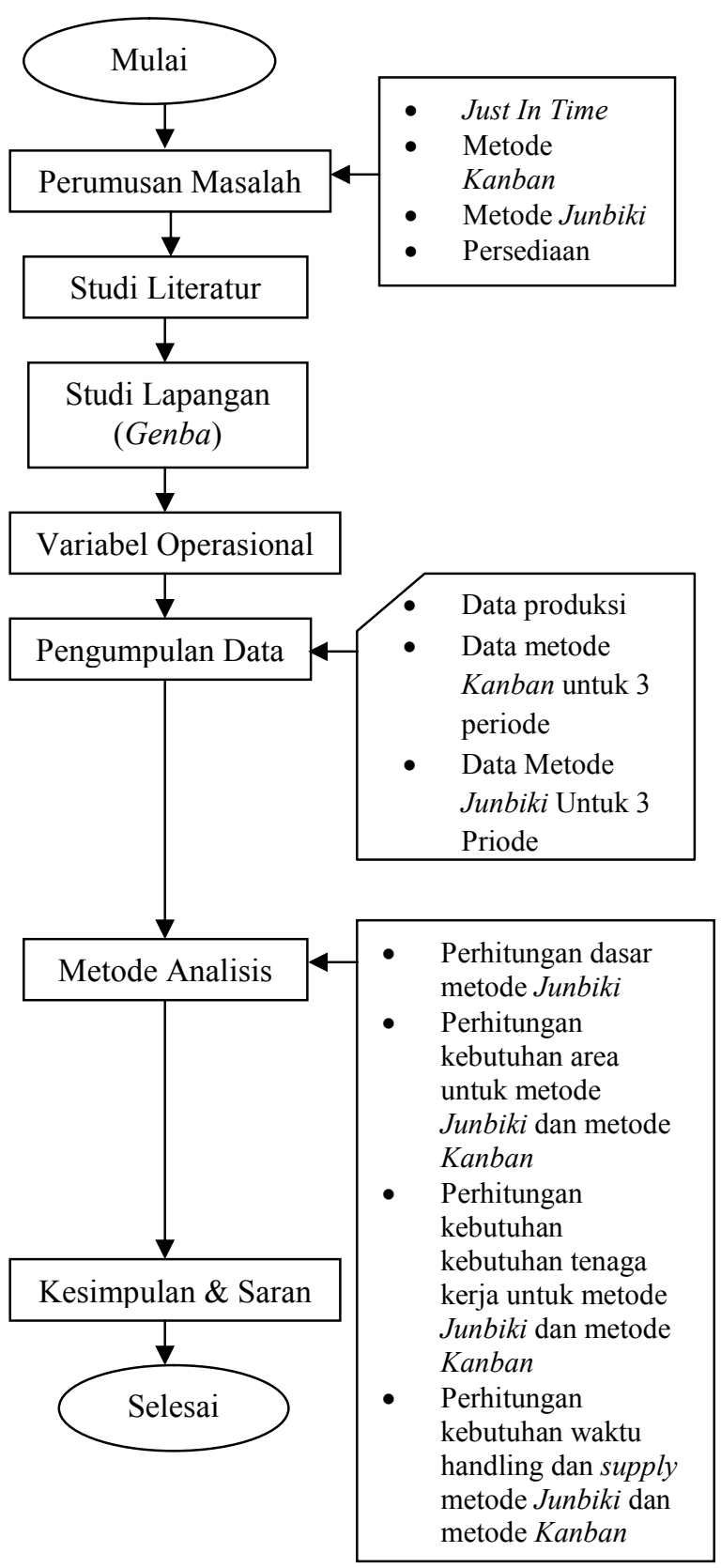

Gambar 1. Metodologi Penelitian.

Penjelasan untuk langkah - langkah dalam penyelesaian analisis perbandingan metode kanban dengan metode Junbiki adalah sebagai berikut :

\section{A. Perumusan Masalah}

Pada tahap ini penulis melakukan pengamatan untuk mengidentifikasi masalahmasalah yang terjadi pada metode Kanban. Masalah - masalah tersebut nantinya akan dipecahkan menggunakan metode Junbiki. 
Tabel 1. Variabel Operasional

\begin{tabular}{|c|c|c|c|}
\hline Variabel & Definisi & Ukuran & Skala \\
\hline $\begin{array}{l}\text { Metode } \\
\text { Kanban }\end{array}$ & $\begin{array}{l}\text { Kanban adalah suatu alat untuk mencapai } \\
\text { produksi JIT (Yasuhiro Monden. 1995:23). }\end{array}$ & $\begin{array}{ll}\text { - } & \text { Kebutuhan } \\
\text { luas area. } \\
\text { - } \quad \text { Kebutuhan } \\
\text { tenaga kerja. } \\
\text { - } \quad \text { Kebutuhan } \\
\text { waktu } \\
\text { handling dan } \\
\text { supply. }\end{array}$ & Rasio \\
\hline $\begin{array}{l}\text { Metode } \\
\text { Junbiki }\end{array}$ & $\begin{array}{l}\text { Junbiki adalah suatu sistem pengiriman } \\
\text { (delivery) yang menggunakan sistem } \\
\text { pemesanan (order) dengan menggunakan } \\
\text { faksimili yang sesuai dengan urutan } \\
\text { produksi (heijunka pattern) di lini produksi } \\
\text { (Yasuhiro Monden, 1995). }\end{array}$ & $\begin{array}{ll}\text { - } & \text { Kebutuhan } \\
\text { luas area. } \\
\text { - } & \text { Kebutuhan } \\
\text { tenaga kerja. } \\
\text { - } \\
\text { Kebutuhan } \\
\text { waktu } \\
\text { handling dan } \\
\text { supply. }\end{array}$ & Rasio \\
\hline Persediaan & $\begin{array}{l}\text { Persediaan adalah suatu aktiva yang } \\
\text { meliputi barang-barang milik perusahaan } \\
\text { dengan maksud untuk dijual dalam satu } \\
\text { periode usaha yang normal, termasuk barang } \\
\text { yang dalam pengerjaan atau proses produksi } \\
\text { menunggu masa penggunaannya pada } \\
\text { proses produksi (Prasetyo, 2006:65). }\end{array}$ & $\begin{array}{l}\text { Kebutuhan } \\
\text { luas area. } \\
\text { - } \text { Kebutuhan } \\
\text { tenaga kerja. } \\
\text { - } \quad \text { Kebutuhan } \\
\text { waktu } \\
\text { handling dan } \\
\text { supply. }\end{array}$ & Rasio \\
\hline
\end{tabular}

\section{B. Studi Literatur}

Langkah kedua setelah melakukan perumusan masalah, penulis melakukan studi literatur. Dalam langkah ini penulis melakukan pengkajian terhadap sejumlah teori-teori yang berkaitan dengan just in time, metode Kanban, metode Junbiki, dan persediaan.

\section{Studi Lapangan (Genba)}

Setelah masalah - masalah yang ada dirumuskan dan dipelajari teori - teori yang mendukung, maka penulis melakukan studi lapangan (genba) mengenai metode kanban dan metode Junbiki di lapangan. Studi lapangan diperlukan agar penulis bisa berinteraksi secara langsung dengan alur proses dari metode kanban dan metode junbiki sehingga ada gambaran awal mengenai metode tersebut.
D. Variabel Operasional

Penjabaran konsep - konsep yang akan diteliti, sehingga dapat dijadikan pedoman guna menghindari kesalah pahaman dalam menginterprestasikan permasalahan yang diajukan dalam penelitian. Variabel Operasional sebagaimana tabel 1 diatas.

\section{PENGUMPULAN DATA}

Langkah selanjutnya yaitu pengumpulan data. Pengumpulan data dilakukan setelah melakukan studi lapangan. Penulis melakukan pengumpulan data - data yang ber kaitan dengan permasalahan yang akan dibahas untuk memperkuat analisa penulis, sehingga nantinya diperoleh suatu kesimpulan yang akurat. Data - data tersebut sebagai berikut : 
a. Data produksi selama 3 periode.

b. Data metode kanban yang terdiri dari :

1) Kebutuhan area.

2) Kebutuhan tenaga kerja.

3) Kebutuhan waktu handling dan supply.

c. Data metode Junbiki yang terdiri dari :

1) Kebutuhan area.

2) Kebutuhan tenaga kerja.

3) Kebutuhan waktu handling dan supply.

\section{METODE PENELITIAN}

Data - data yang sudah diperoleh kemudian akan dihitung kebutuhan kebutuhan yang diperlukan untuk implementasi metode Junbiki. Perhitungan tersebut terdiri dari :

- $\quad$ Perhitungan dasar untuk metode Junbiki.

Perhitungan ini adalah perhitungan dasar untuk menghitung apakah part muffler dapat diimplementasikan ke dalam metode Junbiki. Untuk perhitungan ini dapat menggunakan rumus sebagai berikut :

Rumus Take Time :

Take Time $=\frac{\text { Wakku Operasional }}{\text { Jumlah Produl yang Di butuhkan }}$

Jumlah produk yang diperlukan

Rumus Lead time:

Lt.s $=\mathrm{T} \times \mathrm{Q}$

- Perhitungan kebutuhan area untuk metode Junbiki dan metode Kanban .

Perhitungan ini dilakukan untuk mengetahui luas area pada saat metode Junbiki diimplementasikan. Apakah membutuhkan area yang lebih luas atau malah mengurangi area bila dibandingkan dengan metode Kanban. Maka kebutuhan ruang dapat dihitung dengan rumus kebutuhan ruang : $\begin{aligned} \mathrm{L} & =\text { Dimensi dolly / palet. } \\ & =\mathrm{L} \times \mathrm{P} \ldots \ldots \ldots \ldots \ldots \ldots \ldots\end{aligned}$

Dimana ; $\mathrm{L}=$ Luas

- Perhitungan kebutuhan man power untuk metode Junbiki dan metode Kanban.

Perhitungan ini adalah perhitungan untuk menghitung kebutuhan man power metode Junbiki yang nantinya akan dibandingkan dengan metode Kanban. Apakah dengan metode Junbiki dapat mengurangi kebutuhan man power. Untuk menghitung kebutuhan man power ini dapat digunakan rumus sebagai berikut :

Rumus Kebutuhan Man Power :

$\mathrm{MP}=\frac{\mathrm{Wt}}{\text { Total Jam Kerja }}$

Dimana :

- Wt : Waktu untuk melakukan pekerjaan x frekuensi pekerjaan.

- Perhitungan kebutuhan waktu handling dan supply untuk metode Junbiki dan metode Kanban.

Dengan melakukan perhitungan ini. Di harapkan akan ada perbedaan dalam waktu handling dan supply antara metode Junbiki dengan metode kanban. Untuk mengetahui waktu handling dan supply, penulis menggunakan tabel standarisasi kombinasi kerja (TSKK) untuk mengetahui perbedaan waktu handling dan supply antara metode kanban dengan metode Junbiki.

- Kesimpulan Data

Setelah penulis melakukan analisisanalisis diatas maka dapat ditarik kesimpulan terhadap implementasi metode Junbiki, dan bila diperlukan maka penulis akan memberikan saran - saran yang bisa menjadi masukan bagi perusahaan. 
Tabel 2. Data Total Pemakaian Part Muffler di PT. XYZ

\begin{tabular}{c|c|c|c|c|c}
\hline \multirow{2}{*}{ No. } & \multirow{2}{*}{ Periode } & \multicolumn{4}{|c}{ Total Pemakaian Part Muffler (unit) } \\
\cline { 3 - 6 } & & $\mathbf{1 7 5 0 1 E 0 0 1 0}$ & $\mathbf{1 7 5 0 1 E 0 0 2 1}$ & $\mathbf{1 7 5 0 1 E 0 0 3 0}$ & $\mathbf{1 7 5 0 1 \mathrm { E0282 }}$ \\
\hline 1 & Oktober & 48 & 1164 & 168 & 18 \\
\hline 2 & November & 30 & 1050 & 192 & 0 \\
\hline 3 & Desember & 48 & 1000 & 180 & 0 \\
\hline
\end{tabular}

Tabel 3. Data Penerimaan Persediaan Part Muffler PT. XYZ

\begin{tabular}{c|c|c|c|c|c}
\hline \multirow{2}{*}{ No. } & \multirow{2}{*}{ Periode } & \multicolumn{4}{|c}{ Total Penerimaan Persediaan(Pcs) } \\
\cline { 3 - 6 } & & $\mathbf{1 7 5 0 1 E 0 0 1 0}$ & $\mathbf{1 7 5 0 1 E 0 0 2 1}$ & $\mathbf{1 7 5 0 1 E 0 0 3 0}$ & $\mathbf{1 7 5 0 1 E 0 2 8 2}$ \\
\hline 1 & Oktober & 90 & 1200 & 210 & 30 \\
\hline 3 & November & 60 & 1110 & 240 & 0 \\
\hline
\end{tabular}

Tabel 4. Nilai Safety Hours

\begin{tabular}{c|c}
\hline Delivery Time & Safety Hours \\
\hline $1-4$ & 3.0 hours \\
$5-10$ & 2.5 hours \\
$11-14$ & 2.0 hours \\
$15-24$ & 1.5 hours \\
\hline
\end{tabular}

\section{HASIL DAN PEMBAHASAN}

Data - data hasil penelitian ini akan digunakan sebagai dasar perhitungan di pengolahan dan analisis data terdiri dari :

1. Data total pemakaian part muffler pada periode Oktober - Desember 2014 seperti pada tabel 2.

2. Data pemesanan persediaan part muffler dalam metode kanban pada periode Oktober - Desember 2014 seperti pada tabel 3.

3. Standar buffer stock (stok penyangga). Untuk perhitungan buffer stock di dapat menggunakan rumus :

$$
\text { Buffer Sluck (BS) }-\frac{\text { SafetyHours }}{\text { WorkHours }} \times \text { Qly/Day }
$$

Nilai safety hours dapat dilihat di tabel 4.

Adapun contoh perhitungan buffer stock sebagai berikut :

Untuk part muffler (17501E0022) jumlah rata - rata per hari adalah 51 unit, safety hoursuntuk part muffler adalah 2 jam dan work hours (jam kerja) 15 jam, sehingga buffer stock untuk part muffler adalah : 
Tabel 5. Part List Metode Junbiki

\begin{tabular}{c|c}
\hline Part Name & Part Number \\
\hline Muffler Sub Assy & $17501 \mathrm{E} 0010$ \\
Muffler Sub Assy & $17501 \mathrm{E} 0021$ \\
Muffler Sub Assy & $17501 \mathrm{E} 0030$ \\
Muffler Sub Assy & $17501 \mathrm{E} 0282$ \\
\hline
\end{tabular}

BS $=\frac{2}{15} \times 51=6,8 \approx 7$ Unit.

Dari perhitungan dapat dilihat bahwa untuk part muffler selama 2 jam, buffer stock yang tersedia maksimal 7 unit.

4. Data sistem Kanban selama 3 periode, yang terdiri dari :

a. Data Kebutuhan Area.

b. Data Kebutuhan Tenaga Kerja.

c. Data Kebutuhan Waktu handling dan supply.

Data - data yang telah diperoleh dari pengumpulan data, selanjutnya akan diolah menjadi dasar perhitungan yang akan dipergunakan untuk analisis data. Perhitungan tersebut meliputi :

\section{Perhitungan Dasar Metode Junbiki}

Barang yang akan dianalisa untuk metode Junbiki adalah part muffler dari supplier yaitu PT. TTI. Alasan mengapa barang ini diimplementasikan ke metode Junbiki, karena persediaan part muffler terlalu banyak yang berdampak kepada kebutuhan area yang cukup luas, kebutuhan tenaga kerja, kebutuhan waktu handling dan supply yang lama dan part muffler sudah sesuai dengan syarat - syarat part Junbiki yaitu berdimensi besar, barang tersebut merupakan harigami part (dalam hal ini part muffler mempunyai variant yang banyak walaupun model dan bentuknya sama), merupakan barang yang langsung masuk ke lini perakitan.
Barang - barang yang akan dianalisa diambil dari jenis mobil truk dan bis, dimana barang - barang tersebut berdimensi dan warna yang sama tetapi part number (nomor barang) yang berbeda. Barang - barang tersebut dapat dilihat di tabel 5 diatas.

Selain barang yang memenuhi syarat, supplier PT. TTI harus memenuhi syarat sistem Junbiki yang dimana waktu infomasi $<$ waktu proses dan alat transportasi harus bisa mengimbangi lead time dari PT. TTI ke PT. XYZ. Data - data perhitungan yang diperlukan adalah :

a. Tack time $=10$ menit.

b. Jumlah Lot Pengiriman $=30$ unit.

c. Titik pemasangan untuk muffler $=56$ Unit.

d. Stok di lini $=8$ unit.

e. Stok di lini sub assy $=4$ unit.

f. Pengiriman ke lini dari $s u b$ assy $=4$ unit.

g. Waktu pengiriman dari supplier ke perusahaan $=45$ menit.

Dari data diatas, maka waktu proses dapat dihitung sebagai berikut :

Unit pemasangan $=56-8-4-4=40$ unit, sehingga :

a. $\quad$ Lead time proses $=10$ menit $\mathrm{x} 40$ unit $=$ 400 menit.

b. Data ukuran lot $=30$ unit/pengiriman $\mathrm{x}$ 10 menit $=300$ menit.

c. Waktu pengiriman email dari perusahaan ke supplier $=2$ menit.

d. Waktu memuat di supplier $=10$ menit.

e. Waktu pengiriman dari supplier $=45$ menit. 
Tabel 6. Kebutuhan Area Metode Kanban

\begin{tabular}{c|c|c|c|c|c}
\hline Periode & $\begin{array}{c}\text { Temporary } \\
\text { Receiving } \\
\text { Area } \\
\left(\mathbf{m}^{\mathbf{2}}\right)\end{array}$ & $\begin{array}{c}\text { Storage } \\
\text { Logistic } \\
\left.\mathbf{( m}^{\mathbf{2}}\right)\end{array}$ & $\begin{array}{c}\text { Storage } \\
\text { Unpacking } \\
\text { Supply } \\
\left(\mathbf{m}^{\mathbf{2}}\right)\end{array}$ & $\begin{array}{c}\text { Temporary } \\
\text { Storage } \\
\text { Sub Assy } \\
\left.\mathbf{( m}^{\mathbf{2}}\right)\end{array}$ & $\begin{array}{c}\text { Total } \\
\text { Area } \\
\left(\mathbf{m}^{\mathbf{2}}\right)\end{array}$ \\
\hline Oktober & 2,86 & 11,44 & 11,44 & 5,72 & 31,46 \\
November & 2,86 & 11,44 & 11,44 & 5,72 & 31,46 \\
Desember & 2,86 & 11,44 & 11,44 & 5,72 & 31,46 \\
\hline
\end{tabular}

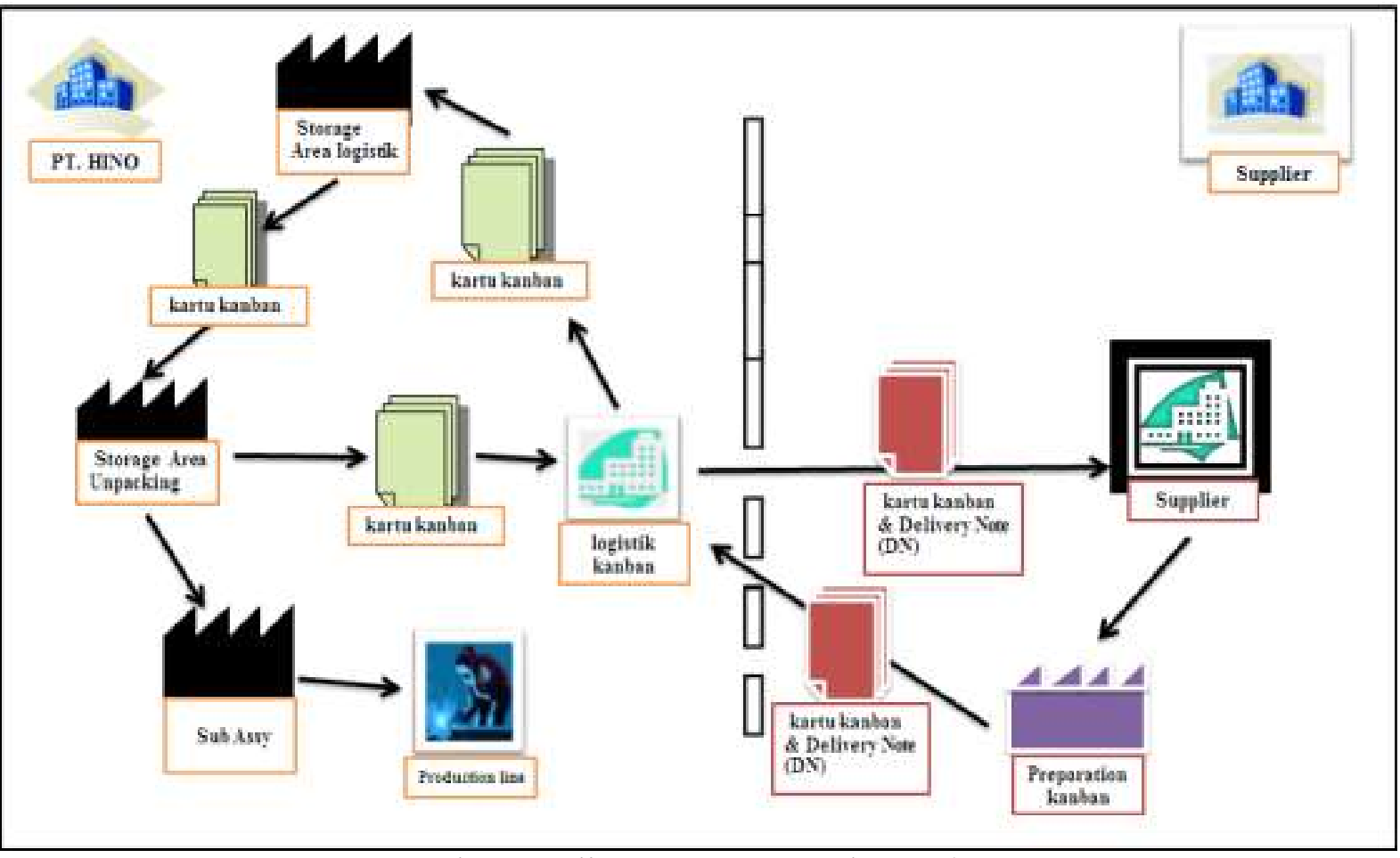

Gambar 2. Aliran Proses Metode Kanban.

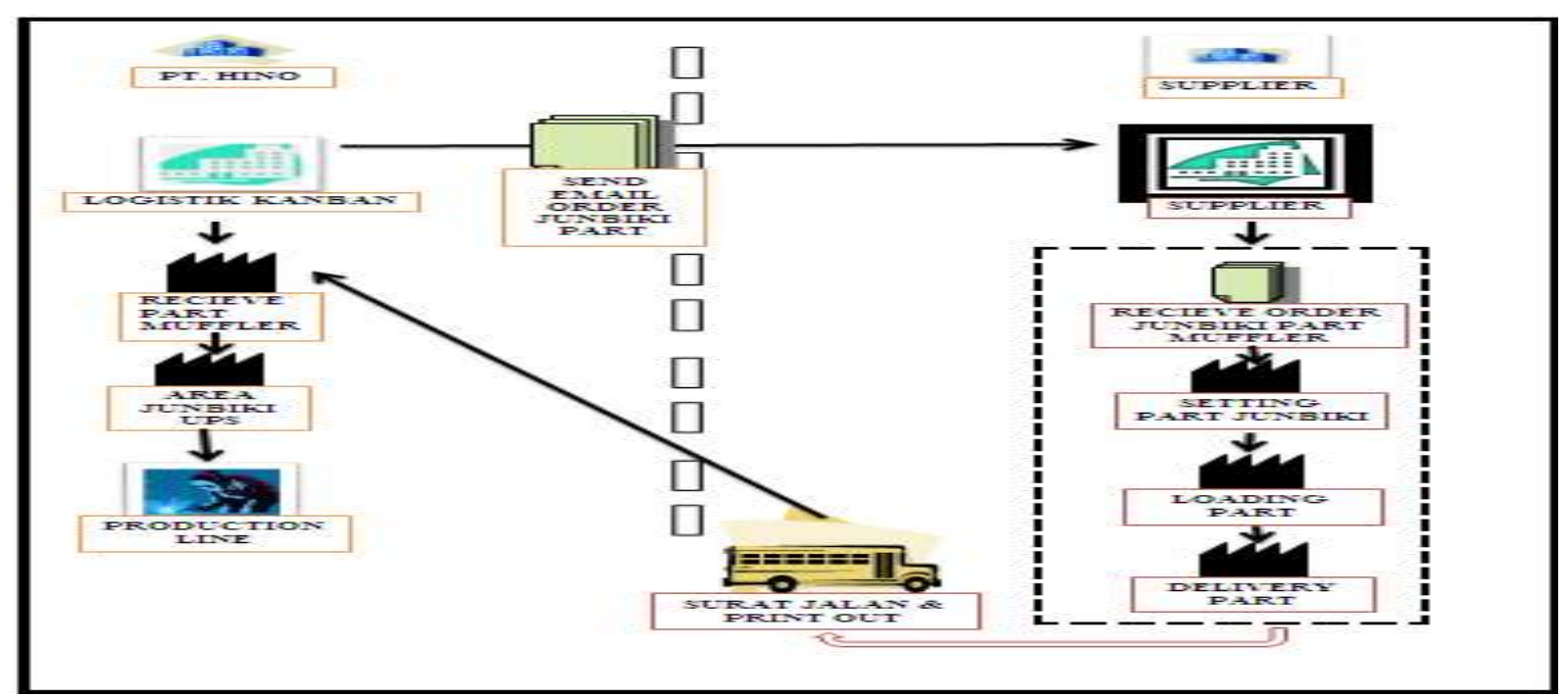

Gambar 3. Aliran Proses Metode Junbiki. 
Tabel 7. Komposisi Palet Metode Junbiki

\begin{tabular}{c|c|c}
\hline Part Name & Part No. & Total Palet \\
\hline Muffler Sub Assy & $17501 \mathrm{E} 0010$ & \\
Muffler Sub Assy & $17501 \mathrm{E} 0021$ & \\
Muffler Sub Assy & $17501 \mathrm{E} 0031$ & 1 Palet \\
Muffler Sub Assy & $17501 \mathrm{E} 0282$ & \\
\hline
\end{tabular}

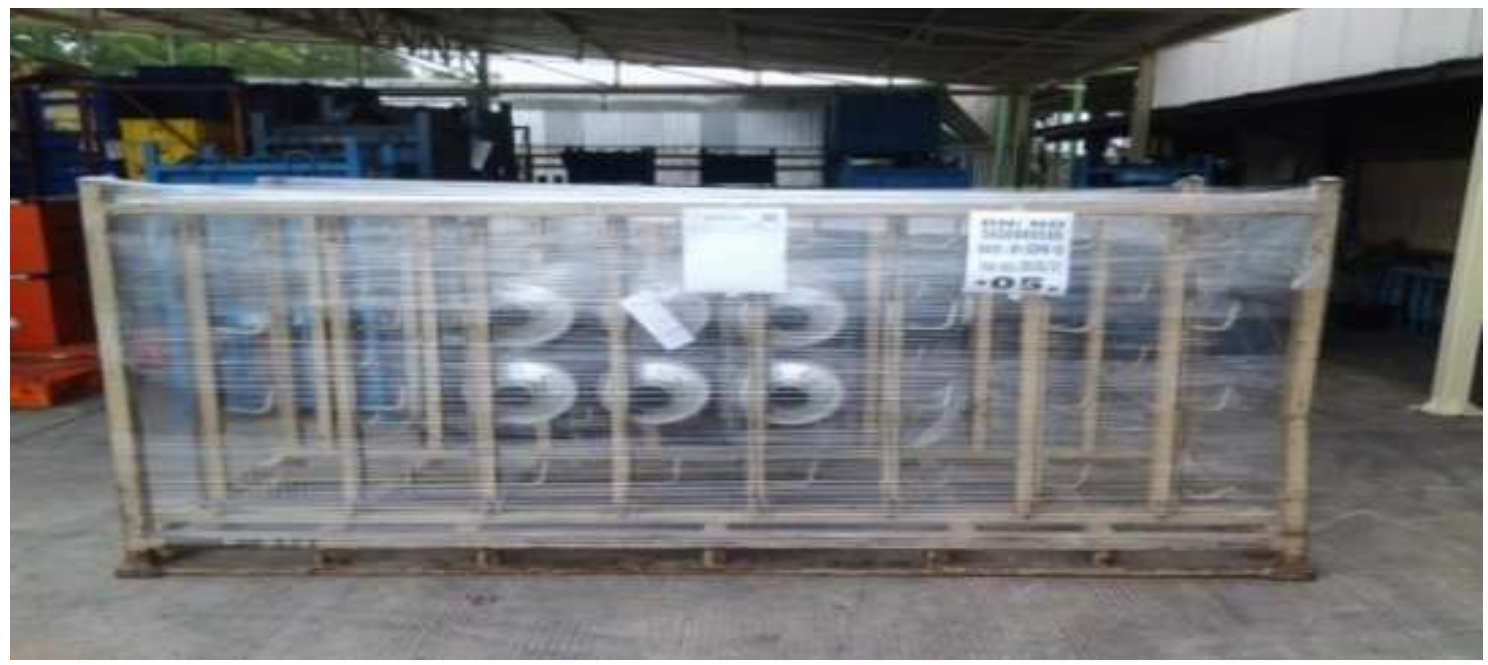

Gambar 4. Komposisi Palet Kanban.

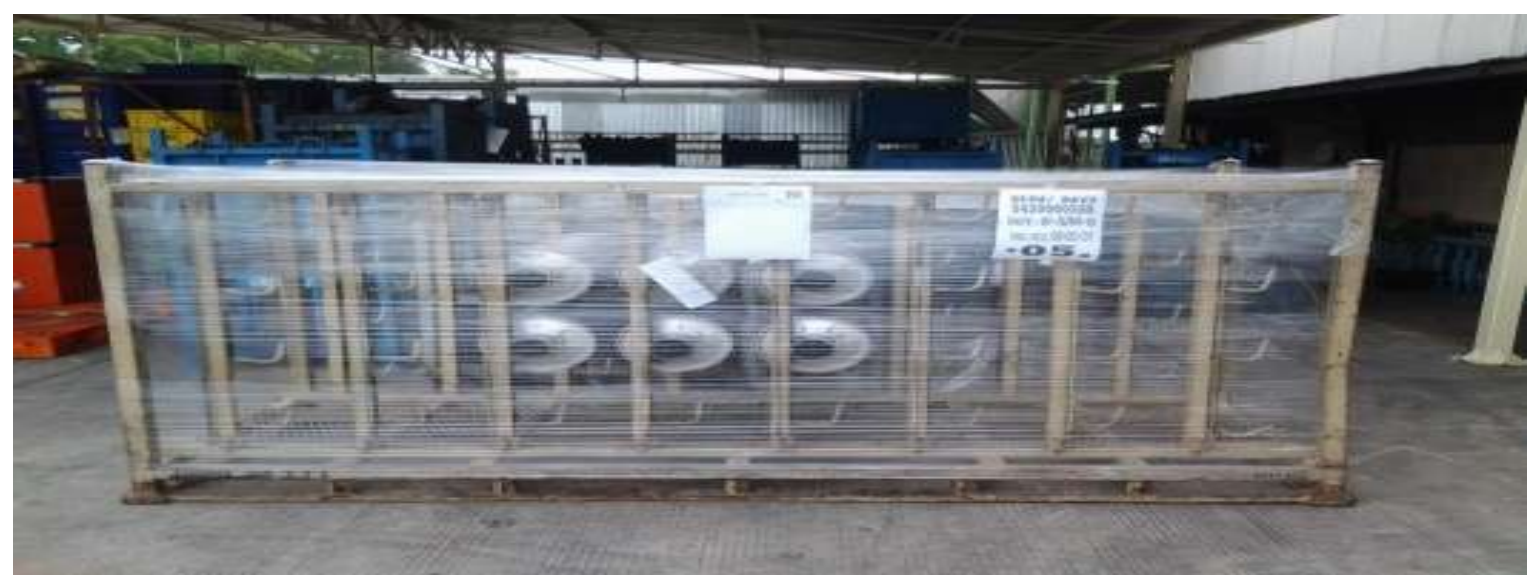

Gambar 5. Komposisi Palet Junbiki.

f. Waktu unloading (membongkar) di perusahaan $=10$ menit.

g. Waktu supply ke sub assy $=10$ menit.

h. Waktu informasi $=\mathrm{b}+\mathrm{c}+\mathrm{d}+\mathrm{e}+\mathrm{f}+\mathrm{g}=$ $300+2+10+45+10+10=377$ menit.

Dari perhitungan diatas didapat waktu proses 400 menit dan waktu informasi 377 menit. Syarat implementasi Junbiki sistem adalah waktu informasi < waktu proses, sehingga sistem Junbiki dapat di implementasikan untuk part muffler karena waktu informasi < waktu proses yaitu 377 menit $<400$ menit. Setelah menghitung syarat - syarat implementasi metode Junbiki agar dapat berjalan, maka alur proses dari PT. TTI ke PT. XYZ akan berubah karena perubahan metode Junbiki ini.

Aliran proses sebelum dan sesudah implementasi metode Junbiki dapat dilihat di gambar 2 diatas yaitu gambar aliran proses sebelum implementasi metode Junbiki 
Tabel 8. Kebutuhan Area Metode Junbiki

\begin{tabular}{c|c|c|c|c|c}
\hline Periode & $\begin{array}{c}\text { Temporary } \\
\text { Receivig XYZ } \\
\text { Area }\end{array}$ & $\begin{array}{c}\text { Storage } \\
\text { Logistik }\end{array}$ & $\begin{array}{c}\text { Area Junbiki } \\
\text { Unpacking }\end{array}$ & Storage Sub Assy & $\begin{array}{c}\text { Total } \\
\text { Area }\end{array}$ \\
\hline Januari & - & - & $2,86 \mathrm{~m}^{2}$ & - & $2,86 \mathrm{~m}^{2}$ \\
Februari & - & - & $2,86 \mathrm{~m}^{2}$ & - & $2,86 \mathrm{~m}^{2}$ \\
\hline
\end{tabular}
$\mathbf{L}$
u
a
$\mathbf{S}$
A
$\mathbf{r}$
e
$\left(\mathrm{m}^{2}\right)$

Gambar 6. Perbandingan Kebutuhan Area Antara Kanban dengan Metode Junbiki.

(metode Kanban) dan untuk gambar 3. yaitu gambar aliran proses setelah implementasi metode Junbiki.

2. Perhitungan Kebutuhan Luas Area

Perhitungan Kebutuhan Luas Area Sistem Kanban. Dari data metode Kanban, kebutuhan luas area yang diperlukan untuk penurunan part muffler dari mulai penyimpanan di area logistik sampai dengan masuk ke area produksi dapat dilihat di tabel 6 diatas.
Perhitungan Kebutuhan Area Sistem Junbiki. Sedangkan untuk kebutuhan area metode Junbiki mengacu pada dimensi palet. Berikut ini adalah perhitunganya :

- Proses order barang melalui e-mail dilakukan 1 kali, 1 email $=30$ unit.

- Kapasitas 1 pallet yaitu 30 unit. 
Tabel 9. Reduksi Kebutuhan Luas Area Metode Kanban dan Junbiki

\begin{tabular}{|c|c|c|c|c|c|c|}
\hline \multirow{2}{*}{ Periode } & \multicolumn{2}{|c|}{$\begin{array}{l}\text { Kebutuhan Luas } \\
\text { Area }\left(\mathbf{m}^{2}\right)\end{array}$} & \multirow{2}{*}{$\begin{array}{l}\text { Reduksi } \\
\quad\left(\mathrm{m}^{2}\right)\end{array}$} & \multirow{2}{*}{$\begin{array}{c}\text { Reduksi } \\
\text { (\%) }\end{array}$} & \multirow{2}{*}{$\begin{array}{c}\text { Harga Sewa } \\
\left(\mathrm{Rp} / \mathrm{m}^{2}\right) \text { Tahun }\end{array}$} & \multirow{2}{*}{ Reduksi (Rp) } \\
\hline & $\begin{array}{l}\text { Metode } \\
\text { Kanban }\end{array}$ & $\begin{array}{l}\text { Metode } \\
\text { Junbiki }\end{array}$ & & & & \\
\hline Oktober & 31,46 & 2,86 & 28.6 & $91 \%$ & 200.000 & 5.720 .000 \\
\hline November & 31,46 & 2,86 & 28.6 & $91 \%$ & 200.000 & 5.720 .000 \\
\hline Desember & 31,46 & 2,86 & 28.6 & $91 \%$ & 200.000 & 5.720 .000 \\
\hline
\end{tabular}

- Total pallet setiap pengiriman 1 palet.

- Total pengiriman 30 unit.

- $\quad$ Dimensi palet $=2,6 \mathrm{~m} \mathrm{x} \mathrm{1,1} \mathrm{m}$.

Maka kebutuhan ruang untuk sistem Junbiki pada part muffler adalah :

$\mathrm{L}=2,6 \times 1.1=2,86 \mathrm{~m}^{2}$

$S r=$ Stock require, dimana disini adalah total palet setiap pengiriman yaitu 1 palet. Jadi kebutuhan ruang dapat dihitung sebagai berikut :

Kebutuhan ruang $(\mathrm{KR})=\mathrm{Sr} x \mathrm{~L} \ldots \ldots \ldots \ldots \ldots \ldots . .(7)$

$$
=1 \times 2,86=2,86 \mathrm{~m}^{2} \text {. }
$$

Kebutuhan ruang untuk metode Junbiki adalah $2,86 \mathrm{~m}^{2}$, dalam satu kali pengiriman pada metode Junbiki terdiri dari 1 palet dan komposisi palet juga dapat berpengaruh dalam reduksi ruangan. Di dalam tabel 7 . adalah komposisi yang ada dalam metode Junbiki. Dalam tabel tersebut dapat dilihat bahwa komposisi dalam metode junbiki terdapat berbagai jenis muffler yang disatukan penyimpanan dalam satu palet. Pada gambar 4 dan gambar 5 diatas dapat menjelaskan ilustrasi tentang komposisi kedua metode ini.
Konsep metode Junbiki adalah zero stock atau nol stok, maka kebutuhan ruang yang dibutuhkan untuk setiap periode adalah sama yaitu $2,86 \mathrm{~m}^{2}$ secara tabel dan grafik dapat dilihat di tabel 8 diatas.

Agar dapat terlihat secara jelas, perbandingan kebutuhan area untuk masingmasing metode dapat dilihat di gambar 6 diatas. Dari gambar 6 grafik perbandingan kebutuhan metode Kanban dan metode Junbiki diatas, dapat dilihat bahwa kebutuhan area untuk metode Junbiki lebih sedikit dibandingkan dengan metode Kanban. Karena area yang terpakai untuk metode Junbiki hanya area Junbiki, yaitu area Junbiki unpacking. Sedangkan area metode Kanban terdiri dari temporary receiving area, storage logistic, storage unpacking supply, dan storage sub assy. Untuk mengeahui lebih jelas mengenai reduksi - reduksi area dapat dilihat pada tabel 9 diatas memperlihatkan reduksi - reduksi yang lengkap dari mulai reduksi area, prosentase, reduksi secara nilai uang.

Terlihat jelas bahwa dengan implementasi metode Junbiki kebutuhan area dapat berkurang, selama tiga periode kebutuhan area berkurang rata - rata 91\%. Hasil ini membuktikan bahwa metode Junbiki lebih baik daripada metode Kanban. 
Tabel 10. Kebutuhan Tenaga Kerja untuk Metode Kanban

\begin{tabular}{c|c|c|c|c|c}
\hline Periode & Good Receipt & MSP & Kanban & Collecting Kanban & Total \\
\hline Oktober & 1 Orang & 2 Orang & 1 Orang & 1 Orang & 5 Orang \\
November & 1 Orang & 2 Orang & 1 Orang & 1 Orang & 5 Orang \\
Desember & 1 Orang & 2 Orang & 1 Orang & 1 Orang & 5 Orang \\
\hline
\end{tabular}

Tabel 11. Deskripsi Pekerjaan Tenaga Kerja untuk Metode Kanban

\begin{tabular}{c|c|l}
\hline No. & Tenaga Kerja & \multicolumn{1}{c}{ Deskripsi Pekerjaan } \\
\hline 1 & Good Receipt & $\begin{array}{l}\text { Menerima dan mengecek barang dari supplier sesuai dengan } \\
\text { Delivery Note (DN) dan membuat surat jalan palet dan box } \\
\text { kosong, filling Delivery Note (DN), 2S. } \\
\text { Loading dan Unloading part-part MSP, supplay part - part MSP } \\
\text { dan Menyimpan part - part MSP sesuai dengan indikasi part, 2S. } \\
\text { Membuat order, mengecek control stock, follow up supplier,filling } \\
\text { DN dan Membuat Critical Part, Membuat Delivry Problem } \\
\text { Supplier (DPS), 2S. } \\
\text { Mengumpulkan kanban disetiap pos kanban dan memasukan } \\
\text { kanban kedalam rak order kanban, Receiv DN ke sistem. }\end{array}$ \\
\hline
\end{tabular}

3. Perhitungan Kebutuhan Tenaga Kerja

a. Data metode kanban untuk kebutuhan tenaga kerja dari data metode kanban, kebutuhan tenaga kerja yang diperlukan untuk loading part muffler dari mulai pengecekan barang sampai proses supply dapat dilihat di tabel 10. Kemudian deskripsi pekerjaan dari masing - masing tenaga kerja untuk metode kanban dapat dilihat di tabel 11 . b. Perhitungan metode junbiki untuk kebutuhan tenaga kerja sedangkan untuk kebutuhan tenaga kerja metode junbiki, jumlah tenaga kerja metode junbiki lebih sedikit bila dibandigkan dengan metode kanban. Pada metode Junbiki untuk tenaga kerjadi area MSP dapat dikurangi menjadi satu orang. 
Tabel 12. Total Waktu Melakukan Pekerjaan MSP ( dalam detik)

\begin{tabular}{|c|c|c|c|c|c|c|c|c|c|c|c|c|c|}
\hline \multirow[t]{2}{*}{ Periode } & \multicolumn{3}{|c|}{$\begin{array}{l}\text { Loading dan } \\
\text { Unloading part- } \\
\text { part MSP }\end{array}$} & \multicolumn{3}{|c|}{$\begin{array}{l}\text { Supplay Part - } \\
\text { part MSP }\end{array}$} & \multicolumn{3}{|c|}{$\begin{array}{c}\text { Menyimpan } \\
\text { part - part MSP } \\
\text { sesuai dengan } \\
\text { indikasi part }\end{array}$} & \multicolumn{3}{|c|}{$2 S$} & \multirow[t]{2}{*}{ Total } \\
\hline & Waktu & Fre & Total & Waktu & Fre & Total & Waktu & Fre & Total & Waktu & Fre & Total & \\
\hline Oktober & 10 & 6 & 60 & 10 & 14 & 140 & 10 & 6 & 60 & 15 & 1 & 15 & 275 \\
\hline November & 10 & 6 & 60 & 10 & 12 & 120 & 10 & 6 & 60 & 15 & 1 & 15 & 255 \\
\hline Desember & 10 & 6 & 60 & 10 & 10 & 100 & 10 & 6 & 60 & 15 & 1 & 15 & 235 \\
\hline
\end{tabular}

- Perhitungan Tenaga Kerja MSP

Untuk menghitung kebutuhan tenaga kerja dari sebuah pekerjaan, kita perlu mengetahui dulu detail deskripsi pekerjaan yang dilakukan. Di mana detail pekerjaan yang ada, kemudian dihitung, berapa lama melakukan pekerjaan tersebut dan jumlah frekuensinya. Adapun Rumus untuk menghitung kebutuhan tenaga kerja adalah :

$$
\mathrm{MP}=\frac{\Sigma W \mathrm{t}}{\text { Total Jam Kerja }}
$$

Ket : Wt $=$ waktu untuk melakukan pekerjaan $\mathrm{x}$ frekuensi Pekerjaan.

Wt adalah waktu total untuk melakukan pekerjaan.

Pada tabel 12, total waktu melakukan pekerjaan MSP, menunjukkan bahwa, waktu total tiap - tiap periode juga frekuensi masing - masing.
Dimana Frekuensi telah ditentukan diawal, yaitu jumlah pengiriman PT. TTI ke PT. XYZ. Tiap periode akan berbeda karena jumlah pengiriman tergantung dari produksi tiap bulannya.

Setelah menetukan $\mathrm{Wt}$, kemudian menentukan working hours. Kebijakan yang diambil oleh PT. XYZ untuk working hours adalah :

- Total jam kerja $=8$ jam $=8 \times 60=480$ menit.

- Total istirahat $=60$ menit.

- Working hours $=480-60=420$ menit.

Maka tenaga kerja untuk tiap - tiap periode dapat dilihat di tabel 13. 
Tabel 13 Total Tenaga Kerja MSP Untuk Metode Junbiki

\begin{tabular}{c|c|c|c}
\hline \multirow{2}{*}{ Periode } & \multicolumn{3}{|c}{ Tenaga Kerja (TK) } \\
\cline { 2 - 4 } & Wt & Wh & Total MP \\
\hline Oktober & 275 & 420 & $0.65 \approx 1$ Orang \\
November & 255 & 420 & $0.60 \approx 1$ Orang \\
Desember & 235 & 420 & $0.55 \approx 1$ Orang \\
\hline
\end{tabular}

Tabel 14 Total Tenaga Kerja untuk Metode Junbiki

\begin{tabular}{c|c|c|c|c|c}
\hline Periode & Good Receipt & MSP & Kanban & Collecting Kanban & Total \\
\hline Oktober & 1 Orang & 1 Orang & 1 Orang & 1 Orang & 4 Orang \\
November & 1 Orang & 1 Orang & 1 Orang & 1 Orang & 4 Orang \\
Desember & 1 Orang & 1 Orang & 1 Orang & 1 Orang & 4 Orang \\
\hline
\end{tabular}

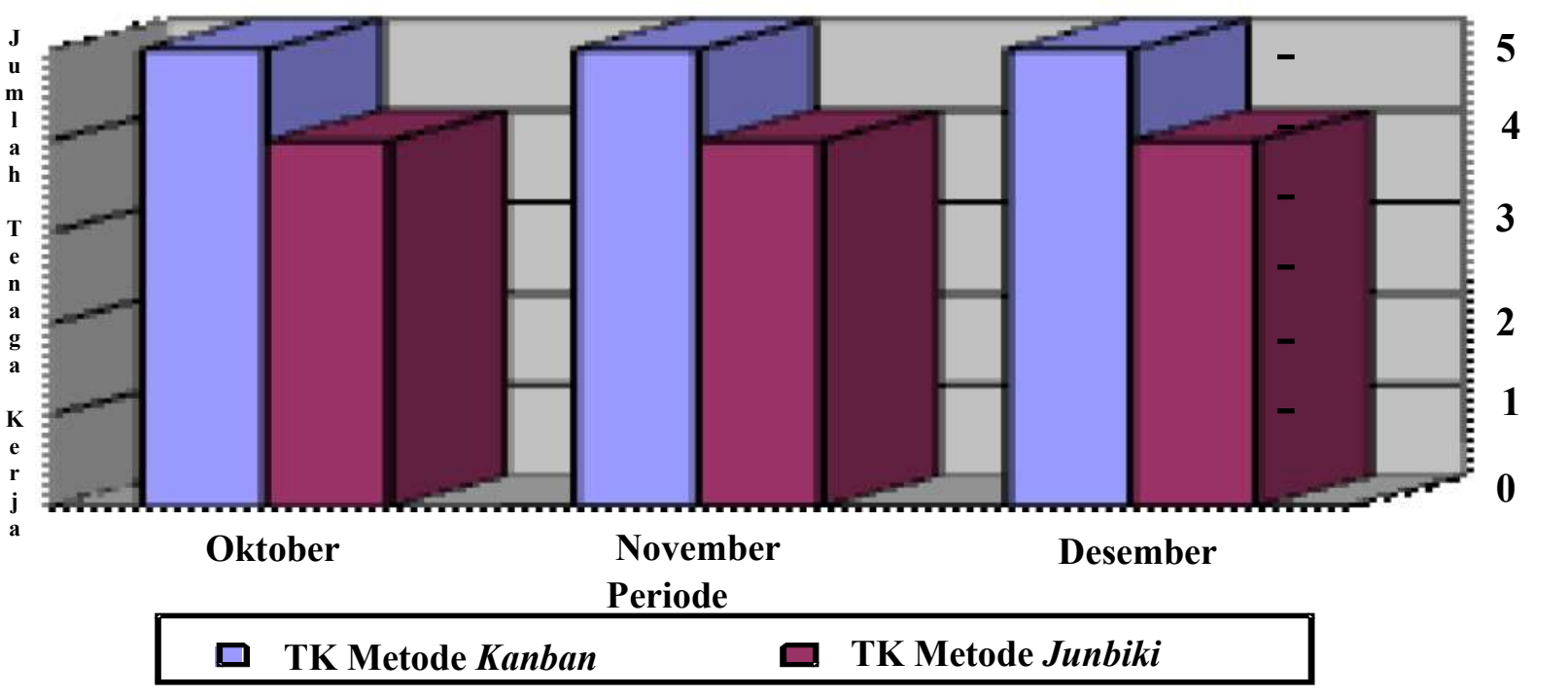

Gambar 7. Perbandingan Kebutuhan Tenaga Kerja (TK) Metode Kanban Dengan Junbiki.

Setelah dihitung tenaga kerja MSP untuk kebutuhan metode junbiki maka total tenaga kerja di tiap - tiap periode adalah seperti tabel 14 diatas. Agar dapat terlihat secara jelas perbandingan kebutuhan tenaga kerja untuk masing - masing metode dapat dilihat di gambar 7.
Dari gambar 7 di atas menunjukan kebutuhan tenaga kerja antara Kanban dengan junbiki dapat dilihat bahwa tenaga kerja junbiki lebih sedikit dibandingkan metode kanban, hal ini disebabkan karena pada junbiki elemen kerja tenaga kerja MSP lebih sedikit dibandingkan dengan metode 
Tabel 15 Perbandingan Tenaga Kerja Kanban dengan Metode Junbiki

\begin{tabular}{c|c|c|c|c}
\hline \multirow{2}{*}{ Periode } & \multicolumn{2}{|c|}{ Kebutuhan TK } & \multirow{2}{*}{$\begin{array}{c}\text { Reduksi } \\
\text { MP }\end{array}$} & Reduksi (\%) \\
\cline { 2 - 3 } & Kanban & Junbiki & 1 & $20 \%$ \\
Oktober & 5 & 4 & 1 & $20 \%$ \\
November & 5 & 4 & 1 & $20 \%$ \\
\hline
\end{tabular}

Tabel 16. Total Waktu Satu Kali Proses Handling dan Supply Metode Kanban

\begin{tabular}{c|c|c|c|c|c|c|c}
\hline \multirow{2}{*}{ Periode } & \multicolumn{7}{c}{ Proses Handling dan Supply (menit) } \\
\cline { 2 - 8 } & $\begin{array}{c}\text { Unloadi } \\
\text { ng }\end{array}$ & $\begin{array}{c}\text { Storage } \\
\text { Part }\end{array}$ & $\begin{array}{c}\text { Storage } \\
\text { Part }\end{array}$ & $\begin{array}{c}\text { Supply } \\
\text { Part }\end{array}$ & $\begin{array}{c}\text { Setting } \\
\text { Part }\end{array}$ & Assy & Total \\
\hline Oktober & 10 & 3 & 3 & 10 & 5 & 10 & 41 \\
November & 10 & 3 & 3 & 10 & 5 & 10 & 41 \\
\hline
\end{tabular}

Kanban sehingga total waktu yang dibutuhkan pada metode Junbiki lebih sedikit dibandingkan dengan metode Kanban.

Untuk perhitungan dapat dilihat di tabel 15. yang memperlihatkan perbandingan kebutuhan tenaga kerja untuk Kanban dan metode Junbiki.

Dari tabel 15 diatas dapat dilihat dengan implementasi metode Junbiki kebutuhan tenaga kerja dapat dikurangi yaitu $20 \%$ dari metode Kanban.
4. Perhitungan Waktu Handling Dan Supply

a. Perhitungan Waktu Handling Dan Supply Metode Kanban

Dari data metode Kanban, kebutuhan waktu handling dan supply untuk part muffler gambar 6. Perbandingan kebutuhan tenaga kerja (TK) metode kanban dengan Junbiki dimulai dari pengaturan part muffler yang akan di supply sesuai dengan FIFO (First In First Out), supply part muffler dan memindahkan part muffler yang ada di area penerimaan sementara ke area storage logistic MSP dapat dilihat pada gambar 8. untuk proses handling dan supply part muffler pada tabel 14 diatas. 


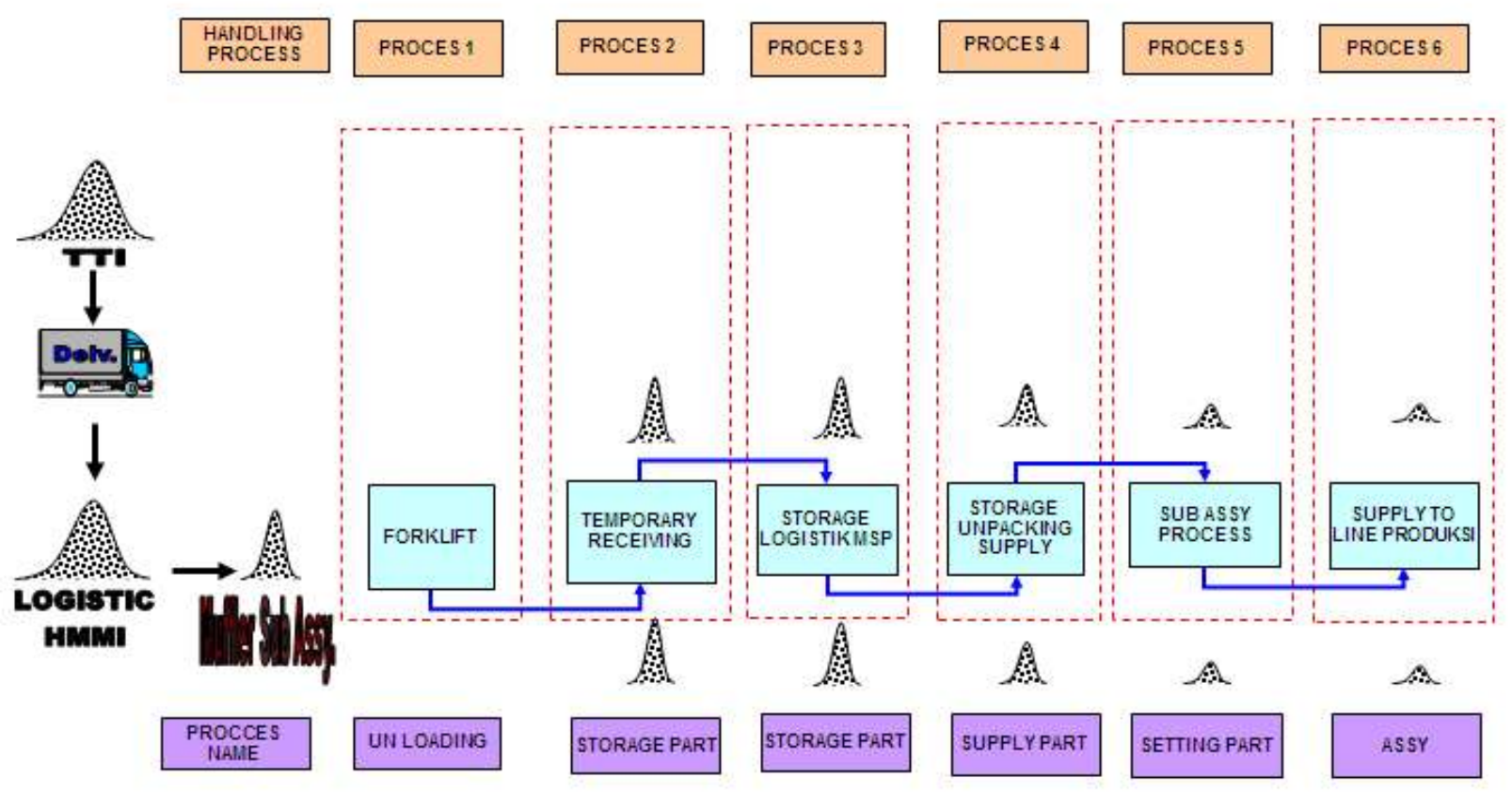

Gambar 8. Proses Handling dan Supply Metode Kanban.

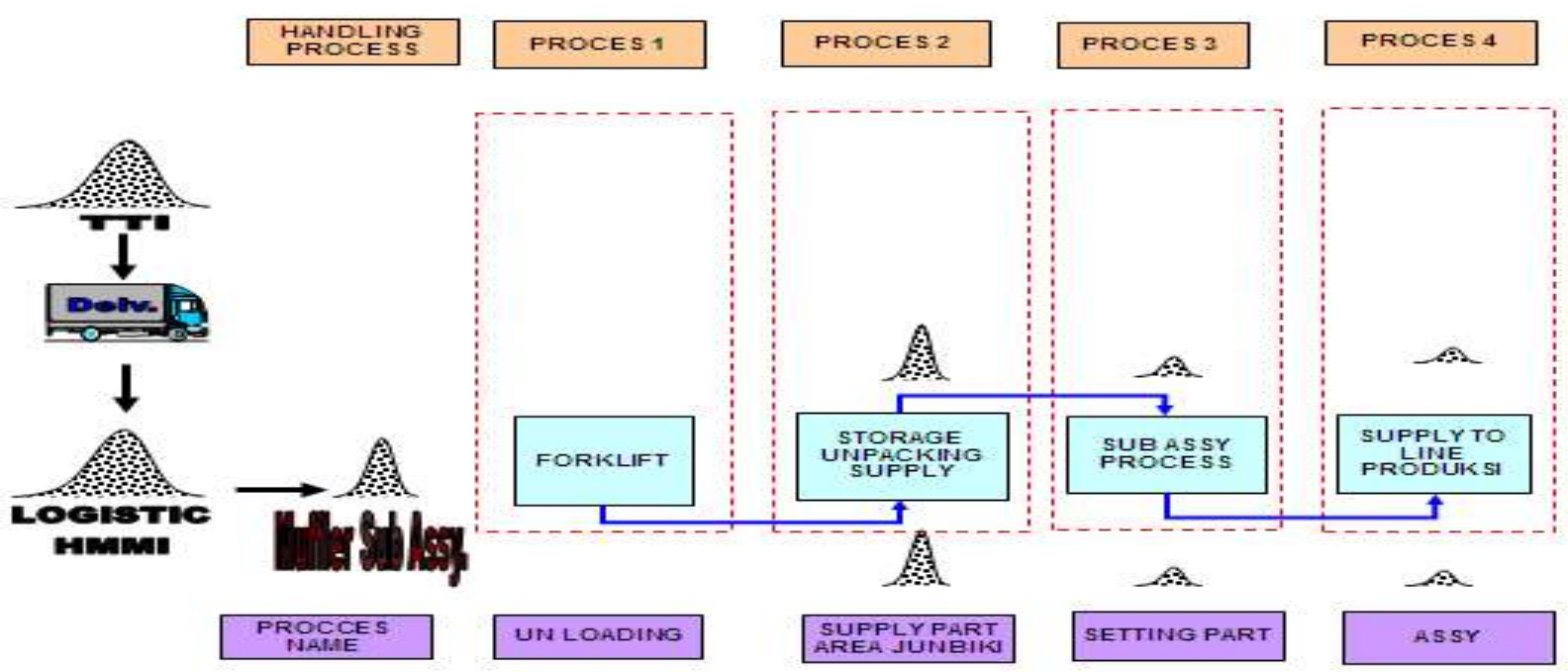

Gambar 9. Proses Handling dan Supply Metode Junbiki.

b. Perhitungan Waktu Handling dan Supply Metode Junbiki

Sedangkan kebutuhan waktu handling dan supply part muffler untuk metode Junbiki. Kebutuhan waktu handling dan supply metode Junbiki lebih sedikit dibandingkan dengan kebutuhan waktu handling dan supply metode Kanban, dikarenakan ada beberapa proses yang dihilangkan dalam proses handling dan supply part muffler untuk metode Junbiki.
Untuk mengetahui jumlah Kebutuhan waktu supply metode junbiki menggunakan tabel standarisasi kombinasi kerja. gambar 9 adalah proses handling dan supply part muffler untuk metode junbiki. Untuk mengetahui total waktu handling dan supply part muffler yang dibutuhkan dapat dilihat pada tabel 17. 
Tabel 17. Total Waktu Satu Kali Proses Handling dan Supply Metode Junbiki

\begin{tabular}{l|c|c|c|c|c}
\hline \multirow{2}{*}{ Periode } & \multicolumn{3}{c|}{ Proces Handling dan Supply (menit) } & \multirow{2}{*}{ Total } \\
\cline { 2 - 5 } & \multirow{2}{*}{ Unloading } & $\begin{array}{c}\text { Suplly Part Area } \\
\text { Junbiki }\end{array}$ & Setting Part & \multirow{2}{*}{ Assy } & \\
\hline \multirow{2}{*}{ Oktober } & 10 & 7 & 5 & 10 & 32 \\
\hline
\end{tabular}

Tabel 18. Perbandingan Kebutuhan Waktu Handling dan Supply Kanban dengan Metode Junbiki

\begin{tabular}{c|c|c|c|c}
\hline \multirow{2}{*}{ Periode } & \multicolumn{2}{|c|}{ Kebutuhan Waktu Handling dan Supply } & \multirow{2}{*}{$\begin{array}{c}\text { Reduksi } \\
\text { (menit) }\end{array}$} & $\begin{array}{c}\text { Reduksi } \\
\text { (\%) }\end{array}$ \\
\cline { 2 - 3 } & Kanban & Junbiki & 9 & $22 \%$ \\
Oktober & 41 & 32 & 9 & $22 \%$ \\
November & 41 & 32 & 9 & $22 \%$ \\
\hline
\end{tabular}

Tabel 19. Perbandingan Perbedaan Kanban dengan Metode Junbiki Berdasarkan Operasional

\begin{tabular}{|c|c|c|c|}
\hline No. & Item & Kanban & Junbiki \\
\hline 1 & Persiapan Part & $\begin{array}{l}\text { Dilakukan oleh operator PT. } \\
\text { XYZ. }\end{array}$ & $\begin{array}{l}\text { Dilakukan oleh PT. } \\
\text { TTI. }\end{array}$ \\
\hline 2 & Order Part & Berdasarkan lot. & $\begin{array}{l}\text { Berdasarkan lini } \\
\text { produksi. }\end{array}$ \\
\hline 3 & Buffer Stock & $\begin{array}{l}\text { Sesuai dengan jumlah kanban } \\
\text { pengaman, } \\
\text { warehouse. }\end{array}$ & Zero Over Stock. \\
\hline 4 & Alat Informasi Pengiriman & Kartu Kanban. & Email. \\
\hline 5 & Kebutuhan Area & $\begin{array}{l}\text { Mengikuti jumlah produksi, dan } \\
\text { penyimpanan sesuai indikasi. }\end{array}$ & $\begin{array}{l}\text { Tetap, walaupun } \\
\text { produksi meningkat } \\
\text { atau menurun. }\end{array}$ \\
\hline 6 & Kebutuhan Tenaga Kerja & Mengikuti jumlah produksi. & $\begin{array}{l}\text { Tetap, walaupun } \\
\text { produksi meningkat. } \\
\text { atau menurun. }\end{array}$ \\
\hline 7 & $\begin{array}{l}\text { Kebutuhan Waktu Handling dan } \\
\text { Supply }\end{array}$ & Mengikuti jumlah produksi. & $\begin{array}{l}\text { Tetap, walaupun } \\
\text { produksi meningkat } \\
\text { atau menurun. }\end{array}$ \\
\hline
\end{tabular}


Terlihat dari tabel 17 bahwa metode Junbiki membutuhkan waktu handling dan supply lebih sedikit dibandingkan dengan metode Kanban, dikarenakan ada dua proses didalam metode Kanbandari 41 menit menjadi 32 menit atau lebih cepat 9 menit dari metode sebelumnya, adapun proses yang dapat dihilangkan di metode Junbiki yaitu proses handling ke storage part. Pada tabel 18 diatas memperlihatkan perbandingan kebutuhan waktu handling dan supply untuk metode Kanban dengan metode Junbiki.

Terlihat bahwa kebutuhan waktu handling dan supply terjadi penurunan. Nilai penurunan setiap periode konstan yaitu $22 \%$. Dari data - data adapun perbandingan dari kedua metode tersebut berdasarkan prosedur operasional dapat dilihat pada tabel 19.

\section{KESIMPULAN}

Berdasarkan data yang yang ada, untuk perbandingan antara metode Kanban dan metode metode Junbiki pada persediaan part muffler,yang ditinjau dari aspek kebutuhan luas area yang semula dengan metode kanban dari 31,46 $\mathrm{m}^{2}$ menjadi 2,86 $\mathrm{m}^{2}$ dengan metode Junbiki dapat mereduksi sekitar 91\% dari kebutuhan luas area, dengan menghilangkan proses operasi temporary receiving area, storage logistic, dan storage sub assy., dimana bisa menghemat biaya sewa selama rata - rata / bulan sekitar Rp 5.720.000,-. Sedangkan untuk kebutuhan tenaga kerja yang semula 5 orang menjadi 4 orang akan mengurangi tenaga kerja 1 orang atau turun sekitar 20\%. Kemudian untuk waktu handling dan supply akan mereduksi sekitar $22 \%$ dari 41 menit menjadi 32 menit., sehingga secara prosedur operasional setelah dibandingkan keseluruhan dapat disimpulkan bahwa metode Junbiki lebih efektif dibandingkan dengan metode Kanban.

\section{DAFTAR PUSTAKA}

Hartini, Sri. dan Rizkiya, Indah. September Perancangan Sistem KanbanUntuk Pelancaran Produksi dan Mereduksi Keterlambatan. UNDIP Semarang, 2013.

Heizer, Jay. Dan Render, Barry. Manajemen Operasi, Jilid 2 edisi 9. Jakarta : Salemba Empat, . 2010.

Indarajid, R.E. Dan R.D. Pranoto, Manajemen Persediaan, Jakarta : PT. Grasindo, 2003.

Kristina, J, Helena. Dan Eri Ignatius. Perbandingan Metode Junbiki - Kanban Ditinjau Dari JIT dan Sumber Daya, Jurnal Teknik Industri, Vol. 7 No.2. Universitas Pelita Harapan, 2005.

Monden, Yasuhiro. Sistem Produksi Toyota. Edisi 1\& 2. Jakarta : Pustaka Binaman Pressindo.

Ohno, Taiichi. Just In Time dalam Sistem Produksi Toyota. Jakarta : Pustaka Binaman Pressindo, 1995.

Prasetyo, Hari dan Nugroho. Munajat Tri dan Pujiati, Asti. "Pengembangan Model Persediaan Dengan Mempertimbangkan waktu Kadaluarsa dan Faktor Unit Diskon”, Jurnal Ilmiah Teknik Industri, Vol. 4 No.3, Universitas Muhammadyah Surakarta, 2006.

PT. Hino Motors Manufacturing Indonesia. Just In Time. Purwakarta, 2011.

PT. Hino Motors Manufacturing Indonesia. Sistem Order. Purwakarta, 2012. 